\title{
Read (Each)Other! - The living library initiative at the University of Pécs
}

\author{
Judit Béres, Dóra Egervári \\ University of Pécs
}

\section{Introduction}

The multicultural program, based on personal contact, comes as "Living Library" from the Danish youth work profession. The living library is a sensitizing method that focuses on equal opportunities based on human dignity, which provides experiential learning and an enlightening effect by inciting reflection, empathy, autonomic and critical thinking. Creating the first living libraries was inspired by the recognition that respect for human rights cannot be confinedmerely from above - to laws or to other social institutions but starting from the level of the individual. The living library - embedded in the metaphor of reading - initiates social dialogue among a wide variety of people and groups, helping to reduce prejudices and stereotypes. It also helps to strengthen tolerance and a deeper understanding of the other's thinking, lifestyle and culture, and their easier acceptance. It is very important that the subject of diversity in this question is ethical and philosophical at the same time. The difference between people and the viewpoint of justice must be a self-evident motive of philosophy and social cohabitation as well. This is part of the necessary conditions in which humanity's self-knowledge and sense of responsibility can reach such a degree, which enables social and global problems to be faced.

The history of living libraries dates back to 1993, when five Danish youths decided to launch a preventive movement against violence. This is how the Foreningen Stop Volden! (Stop the violence!) civil organization was created, which called the attention of Danish youths to the prevention of violence in the form of informal "peer group education" actions. These were based on prior knowledge and own life experiences and were built on group conversation and information exchange.

In 2000, the Director of the largest Northern European summer event, the Roskilde Festival, asked the Foreningen Stop Volden! activists to organize an event within the framework of the festival, which-focusing on nonviolent communication - initiated dialogue and built relationships among youths who attend the festival and represent often opposing subcultures. Ronni Abergel, Asma Mouna and Christoffer Erichsen set up the first Menneskebiblioteket 
(human library) event, where 75 volunteer living books were involved from the festival's audience. Living books - as representatives of a wide variety of cultures, ethnicities, identities and religions - shared their own life experiences with their conversation partners. ${ }^{1}$

Since 2000 - with the English equivalent (human library) of the Danish term and since 2010, under the name of living library - several countries have been hosting living library events. In 2008, Ronni Abergel founded the Copenhagen Human Library Organization umbrella organization, which has popularized and distributed the living library movement worldwide. Today, this method is known in more than 70 countries, thanks to successful local living library events.

In 2001, the first Hungarian living library was opened at the "Civil Island" of the Budapest "Sziget Festival", and it was regularly included in the "Sziget" program in the coming years and became one of the most popular multi-day events. Since then, smaller or larger Budapest or countryside living libraries have been organized in schools, festivals, libraries, ruin pubs and cultural centres (Markó, 2005). ${ }^{2}$ The living library with the largest media coverage currently is the Kazinczy Living Library, which has been waiting for the readers with a modern thematic and a constantly updated book collection since January 2015 in a Budapest ruin pub called "Szimpla Kert".

\section{The operating principles of the living library}

The living library works like a real public library - readers choose from the books they are interested in based on different intentions, then they rent a "copy" for a specified time. While reading, they gain experiences, learn about the world and themselves and finally they return the book and lend another one to their liking. The most important difference is that in the living library

\footnotetext{
1 The history of the initiative and its present-day coverage, a summary of national and international events on the living library can be found on the homepages of multiple umbrella organizations. Next to the http://humanlibrary.org/ central page, the best source of information is the Council of Europe's information page http://www.coe.int/t/dg4/eycb/Programme/livinglibrary_en.asp and the methodological site of the British living library movement http://humanlibraryuk.org/

2 See also the interview with Zoltán Nemes, one of the organizers of the living library of University of Pécs librarian students. In: Markó Anita: Kölcsönadott életek - Élö Könyvtár az elöitéletek ellen. Magyar Narancs, 26 March 2015. 24-25., as well as Galambos Attila and Nyirati András Antidiszkriminációs képzés a gyakorlatban. Romológia, anti-racism thematical volume 2014, 4-5, 175-193.
} 
the „books” are real people, not actors or role-players. They are people who bring their own life story to their readers and primarily represent themselves by talking in a frank conversation about how they live and who they really are. The following points can be used to summarize the basics of living libraries:

1. The most important objective is to promote an intercultural dialogue. In order to do this, it is essential to offer living books that are topical and relevant in the country and within the local societies serving both the dissemination of democratic values and the development of the cohesion of the local community. It is imperative that the books on the event are „,current readings" in the social context of the country. Accordingly, subject variances of living books are almost endless, but are typically selected from the following categories:

- members of religious groups (e.g. Muslim, Jewish, Krishna, Buddhist)

- members of ethnic groups (e.g. Romas/Gypsies, African-Americans, Chinese or other ethnic groups considered as challenging in the country, foreign immigrants, refugees, migrants, or perhaps couples blatantly from other cultures)

- members of youth subcultures (e.g. punk rockers, goths, emos, rappers)

- people with disabilities and addicts (e.g. deaf, blind, disabled, mentally handicapped, drug addicts, alcohol-dependents, people with psychic disorders)

- people discriminated on the basis of their gender identity (e.g. lesbian, gay, bisexual, transgender, queer, intersexual, and parental groups formed from them, such as rainbow families)

- people with lifestyles, habits other than the average, activists, and representatives of different movements (e.g. homeless, tattooed, graffiti artists, vegetarian, vegan, animal rights activist, environmentalist, feminist)

- representatives of professions and activities that are prejudiced (e.g. policemen, public worker, politician, priest, full-time mother, unemployed, workers with disabilities).

2. The most important value mediated by the living library is reception and acceptance based on the understanding of the other's point of view, which is also built on personal interaction, gathered information that clears delusions and experiential learning. Within the living library, we can meet and talk to people, with whom we would not necessarily have 
this opportunity on weekdays, or if we had, we would not dare, could not or would not want to address them. In the living library-during the 30-minute loan period - we have the opportunity to ask questions, with which we can better understand the given person's culture, everyday life, problems, joys and motivations of their behaviour, meaning that we can obtain relevant information and a direct impression on them. The ,reading” and the ,reading experience” emerging in the aftermath contribute to changes in the perspective and to increased empathy and tolerance towards the familiarised people and groups. In the longer term it facilitates the creation of equal opportunities and social dialogue. The living library is a sensitizing tool that requires openness, flexibility, self-reflection and self-criticism from the reader.

3. Dialogicity is a key element of the living library. The living book does not monologize or agitate but has an honest conversation with the reader. Although the task is difficult, it is important for the living book to remain open and do not suffer the conversation but be an active, inquiring and credible participant. In the living library, reading is an interactive process. The "book" may also ask questions to explore the beliefs and experiences of the reader. During the conversation, they should also tolerate the world view and habits of others and they should turn to the views and ideas of others openly, without any aggression.

4. The fourth feature of the living library is the public library-type framework which allows books and readers to easily understand the rules as well as allows the event to be transparent and controllable for the organizers:

- The titles are selected, i.e. who the people to be borrowed will be in our living library.

- The number of books determines the volume of our living library, a small living library works with 8-10 books, while in a big, 25-30 books can be offered. The duration of the event can range from 3-4 hours to a one-week interval.

- Living books are acquired and prepared for the rental. This includes content and formal "cataloguing", during which the book gets a concise title description and keywords for its catalogue card.

- Promote our library services, i.e. the actual event itself.

- The head of the library (project manager) divides the organizational tasks into work phases then assigns smaller expert groups with ,librarians" responsible for carrying out the tasks. 
- The books get on the shelves on the day of the event, where they can be borrowed, and the reader's service is waiting for the readers with catalogues and instructions.

- When the readers arrive in the living library, they are welcome by animators who inform them about the program options available at the event.

- Traditionally, the most common negative stereotypes associated with a given book are listed on the catalogue cards, which are collected with the help of the "books".

- The books that are expected to become bestsellers may include duplicates in our collection.

- The reader and the chosen book retreat to the ,reading room” where they can talk to each other without being disturbed.

- Each loan can take up to 30 minutes while a reader, a couple, or a small group read a "book".

- A ,dictionary" is available for sign- or other foreign language speaking books or readers who can be borrowed next to the book.

- It is an important ,stock protection" principle that the reader should return the book to the reader's service, at the end of the rental, in an intact physical and psychological condition.

- The reader can continuously borrow new titles during the entire event and he/she can request a reservation and renewal for books that interest them at the reading service.

- The books are waiting on the "shelf" during the 5-10 minutes recreation period between the loans.

- The readers who leave the library are asked to give a questionnaire feedback about their reading experience.

- Books are asked to give feedbacks about their readers as well.

- "Scrapping" can be based on written and oral reader feedback.

- Feedback is provided to our books and partner organizations on the basis of the reader feedback questionnaires and our library services are improved.

- For a similar purpose, we have an evaluation meeting with the organizers and possibly the living books as well on the days after the event. 


\section{Living Library at the University of Pécs}

The third-year librarian students of the Department of Library and Information Science have studied pedagogical techniques to develop critical thinking and to foster interactive learning in the course of Critical Approach to Managing Information and Information Sources. They also got acquainted here with the living library method. The group finally got the exam task to create a living library within a project work. In November 2013, we began the methodological preparation for organizing our first living library. We certainly wanted our available books to be current, so we decided together with the students that blind, mentally handicapped and disabled people, members of youth subcultures and members of ethnic and religious groups will be in our offer. We have mobilized our own circle of acquaintances to reach living books, from where "book-fit" private volunteers also emerged. We also looked up - personally or via emailthe local NGOs involved in the themes of books. The city's high schools have trustfully welcome the university's living library initiative and they were willing to send their own students as readers. This trust is key, since organizers of living libraries in schools, as outsiders, often encounter walls of distrust because schools are reluctant to allow unfamiliar civilians to attend their classes arranging sensitizing sessions. Even if this mistrust is largely unfounded, in our case it is clear that recognized NGOs and the university-as background and co-organizers - help to overcome reluctances about professionalism. It is also important to gain the support of teachers and school leadership since it is up to them whether their students can attend our event. In Pécs, after the success of our first two university-organized living libraries we were invited by several teacher librarian colleagues to organize their own mini living library in their school. This is how we got for instance, to the theme day of the Radnóti Miklós Secondary School of Economics in Pécs in December 2015, where-among the development program opportunities offered to students - our librarian students' living library attracted the most visitors. The 4.5-hour mini living library, organized in Radnóti, offered a gay, a visually impaired, a Jewish, two Krishna believers and two sober addictive (ex-drug-dependent) "books". The bestseller of the realised living library was clearly the gay "book" with 10 loans and a total of 34 readers followed by the two sober addictive "books" with 9 loans per person and 32 readers. On the third place was the visually impaired "book" with 8 rentals and 25 readers and booked the most renewals with 4 occasions. The Krishna believer "books" received 7 rentals per person, 22 and 23 rentals total. It indicates the success of the program that except for the Jewish and the 
gay "books", there were renewals of the loans for all books. The only negative reader feedback was the frustration that during the event-by the excessive interest - they did not have access to the wanted books. Based on the positive experiences of the event, we have decided that we will try to organize multiple "outsourced" living libraries in the future.

On 29 April, 2014 and on 12 May, 2015, we held our living library events in one of the halls and interior gardens of the University of Pécs. The location was ideal, civilized and wide spaces gave way to the event. The living library was opened in the early afternoon on both days and the twenty available living "books" were for rental for a total of four hours. For the success of the event, a student team of 15 people worked occasionally, carrying out the tasks in small group work. The main target audience of the living library, according to the original plan, were university students and grade 11-12 high school students. The schools were contacted by the teacher librarian colleagues and were invited to attend the event, expecting up to 15 students per institution. The contribution of teacher librarian colleagues was very important because they knew the local school situation, they could credibly promote the living libraries before their school educator colleagues and they could agitate students to participate. Because of the springtime dates, it was difficult that graduating high school students were more preoccupied with preparing for graduation, therefore, they could not be involved. Consequently, contrary to the original plan, the $2^{\text {nd }}$ and $3^{\text {rd }}$ grade students participated in the event. Winning the other target group, the university students and luring them to the event proved to be even more difficult (Béres, 2017).

\section{Results, feedback}

The evaluation conversations - summing up the work of the organizing students - made it clear that the living library as a working method is instructive because it gives the organizers an opportunity to perform social, librarian and cultural event organizer work at the same time. It was a particularly good opportunity for librarian students to learn about management and teamwork due to the complexity of the project and to learn about how important it is to work together and help each other so that everyone could carry out the subtask and the joint production should be successful. Thus, they have gained practical experience that they couldn't have had with traditional library practices and university education. Finally, for them, just like for the visitors of the event, it 
was possible to expand their worldview, to face their own prejudiced thinking and - last but not least - to experience how effective it can be if library, reading and reading promotion are approached by an innovative way.

There was no complaint about the readers' interest; much more students came than expected from the invited secondary schools even for the previous feedbacks of the schools, to such an extent, that at certain times when the readers arrived in large numbers, we scarcely managed to serve them with living books. The university students were also represented, but on a university-level comparison this was a negligible interest. Overall, there was a lot more interest in the program and more people came than we had expected.

The use of feedback questionnaires is a widespread tool in living libraries and many versions of the questionnaire are known and available on the Internet. Only positive feedback came from readers who answered the questionnaire. To the question of 'what the "reading" gave to them', 'the possibility of personal dialogue' and 'getting to know individual life experiences' were highlighted by most respondents. Many people were motivated to read by the desire to know about the real content and information behind prejudices and stereotypes. Readers were generally interested in the everyday life of their books, their habits and their personal experience on social exclusion, being handicapped or negative discrimination. Among the best features of the books, openness, directness, honesty and the ability of taking on were highlighted. According to the general experience of the questionnaires of the books, everyone had a positive experience of being read. Several people emphasized that being read meant not just self-knowledge and strengthening function but also the desire of information transfer, authentic familiarization of the represented topic, dissemination of knowledge and opinion-forming. The reading events were enriched by the fact that several living books borrowed and read each other and there were organizing students as well who read when they could. In the first year there was a student who served time at the rental desk and as a punk rocker living book at the same. These two, as it turned out, cannot be executed at the same time, so we called her to be living book next year.

The living library was clearly a success in 2014 and 2015. According to the Circulation Desks' reservations and the feedback questionnaires - received from the readers and the living books - in 2014182 people, in 2015125 people read a living book here. This means that we had a bit more visitors since there were always "sight-seeing" people, such as interested university lecturers, teachers who escorted high-school students and inadequate university citizens. They did not take part in the loan, and there were always some who used the services but were reluctant to fill in questionnaires. Based on the loan statistics, 
it can be said that the greatest interest was still in sexual differences, followed by addictions. After them, religious and ethnical differences and finally, people with disabilities came. In connection to the mildly handicapped "book", several people admitted that they did not borrow them because they were afraid they could not understand each other. Unlike our expectations, it was clear that young readers were not interested in the subcultures of their own age group because they were not particularly interested in the punk rocker "book" in either year. There was an exception to this if the book represented a mysterious subculture like goth. The goth boy was among the most read books in 2014 . The average age of readers, this year as well, was characterized by the fact that in majority (43\%), 17-year-old high school students were present at the event, while 16-year-olds accounted for $16 \%$ of all participants. Other age groups, such as 18 to 27 year-olds and adults older than that, accounted for 3-5\% one by one. This ratio does not give a full picture of the age of readers, since $8 \%$ did not set age on the feedback questionnaire or many did not fill out the questionnaire at all. In 2015, the fact that books were borrowed and read by each other also increased the number of readings. Of those who filled out a questionnaire in 2015 as readers, almost everybody rated the library as 5/5. Three people were dissatisfied with the catalogue, which was probably due to congestion at the circulation desk, impatient wait-and-see and the lack of information meanwhile. In the longer term, it is advisable to introduce a wall notice, which can be seen on the websites of British living libraries, about the books that are currently being borrowed or free and what rules apply to library usage and so on. By posting such a table in a central location, readers can find more information about available options at the same time and congestion at the circulation desk can be avoided. Based on the living books questionnaires, the living library was very good; everyone rated the experience for $5 / 5$ and had a positive view of their readers likewise. Only disabled people rated the library as $3 / 5$ as they had fewer readers in both years. In the first year we had supposed that they were not sufficiently aware or specific about their card catalogue but in the second year it turned out that unfortunately, people found the subject generally uninterested. We did unsuccessfully recommend this subject to the readers because it seemed that it was much more promising for young people to know something about an ex-drug addict or a lesbian than to understand exactly what it means to live as a disabled person. It is likely that there will be a significant improvement in the interest in less read books if the students are not locally faced with book topics first but in the context of a brief preparatory briefing or session, they could learn something about the themes of the books. This is where teacher librarians, form teachers and ethics teachers can help, who are trustfully sending their students 
to living library events anyway. It would be equally important to give students the opportunity to discuss their own experiences with living library at school. Thus, the event could have a positive impact not only on the thinking of individuals, but also in on the local community and social dialogue.

\title{
References
}

Abergel, R., Rothemund, A., Titley, G., and Wootsch, P. (2005): Don't judge a book by its cover! The Living Library Organiser's Guide Council of Europe. Council of Europe Publishing, Strasbourg.

Abergel, R., Rothemund, A., Titley, G., and Wootsch, P. (2005): Nézz a boritó mögé! Útmutató az Élö Könyvtár szervezői számára. Európai Ifjúsági Központ, Budapest.

Béres, Judit (2017): „Azért olvasok, hogy éljek”: Az olvasásnépszerüsitéstől az irodalomterápiáig. Kronosz Kiadó, Pécs.

Markó, Anita (2015): Kölcsönadott életek - Élö Könyvtár az elöitéletek ellen. http://magyarnarancs.hu/riport/kolcsonadott-eletek-94285

\begin{abstract}
The history of living libraries dates back to 1993, when five Danish youths decided to launch a preventive movement against violence. The "Living Library" projects were based on prior knowledge and own life experiences and were built on group conversation and information exchange. The librarian students of the Department of Library and Information Science have studied pedagogical techniques to develop critical thinking and to foster interactive learning in the course of Critical Approach to Managing Information and Information Sources. They also got acquainted here with the living library method. The final exam task for the group was to create a living library within a project work. This paper shows the results of these projects.
\end{abstract}

